\title{
Land-use change from poplar to switchgrass and giant reed increases soil organic carbon
}

\author{
Andrea Nocentini ${ }^{1} \cdot$ Andrea Monti $^{1}$
}

Accepted: 8 June 2017 / Published online: 28 June 2017

(C) INRA and Springer-Verlag France SAS 2017

\begin{abstract}
Switchgrass and giant reed can provide a dual contribution in reducing greenhouse-gas emissions through displacing fossil fuels and derivatives and increasing soil organic carbon. However, if it is generally true that displacing fossil fuels with biomass brings favorable effects, there is not as much evidence that perennial grasses increase soil organic carbon, as it mainly depends on the land-use change. The present study investigated, for the first time, the effects on soil organic carbon of the land-use change from poplar to switchgrass and giant reed. We addressed the soil organic carbon variation over 10 years of switchgrass and giant reed succeeding a 30-year poplar. Soil samplings were performed after 3 and 10 years from establishment down to $0.6 \mathrm{~m}$ depth. The results show that although the ability of poplar to store large quantities of soil $\mathrm{C}$ is widely demonstrated, the two perennial crops allowed to further increase soil organic carbon stocks; particularly, giant reed increased soil organic carbon at a double rate than switchgrass $\left(0.19\right.$ and $0.09 \mathrm{~g} \mathrm{~kg}^{-1}$ year $\left.{ }^{-1}\right)$. The variation in soil organic carbon highly affected total greenhouse gas savings as estimated by a life-cycle assessment: $11-35$ and $20-42 \%$ of total savings from switchgrass and giant reed, respectively, derived from increasing soil $\mathrm{C}$ stocks. These results highlight the importance of understanding long-term environmental- and crop-specific land-usechange effects in life-cycle assessments instead of applying coefficients to generic crop categories (e.g., perennial tree/crop) and crop sequences, as it normally happens.
\end{abstract}

Andrea Monti

a.monti@unibo.it

1 Department of Agricultural Sciences, University of Bologna, Viale G. Fanin 44, 40127 Bologna, Italy
Keywords Lignocellulosic · Biofuels · Land-use change · Soil organic carbon $\cdot$ Carbon isotopes $\cdot \mathrm{C}$ savings

\section{Introduction}

Deep-rooted perennial grasses such as switchgrass (Panicum virgatum $\mathrm{L}$.) and giant reed (Arundo donax L.) can provide a dual contribution to greenhouse-gas emission reduction by both storing soil organic carbon (SOC) (Lemus and Lal 2007; Agostini et al. 2015) and producing biomass to displace fossil fuels (Alexopoulou et al. 2015; Schmidt et al. 2015) (Fig. 1). However, if it is true that every year a certain amount of biomass is produced, much uncertainty exists when factoring in SOC variations, which can be positive or negative depending on several intrinsic and extrinsic factors, such as climate, soil type, crop management, and former land use (Garten and Wullschleger 2000; Brandão and Milà i Canals 2013). Especially the former land use impacts SOC stocks as, in most cases, the change to perennial grasses triggers the soil system towards a new equilibrium. New SOC dynamics are principally a result of a change in above- and below-ground vegetation (live $\mathrm{C}$ pools) and in the land management. Typically, perennial grasses increase SOC when replacing arable crops, while they decrease SOC when grown after natural ecosystems or pasturelands (Garten and Wullschleger 2000; Fargione et al. 2008; Qin et al. 2016).

Ideally, dedicated perennial grasses for biofuels and biorefinery are thought to be suited to marginal lands (i.e., areas with a low economic value, considering both productive and ecological perspectives) in order to avoid competition with food crops. However, an unresolved dilemma is whether the cultivation of perennial grasses in marginal areas will maintain SOC unchanged, or if a negative SOC change will nullify the positive effects from fossil-fuel displacement (Fargione et al. 2008). 


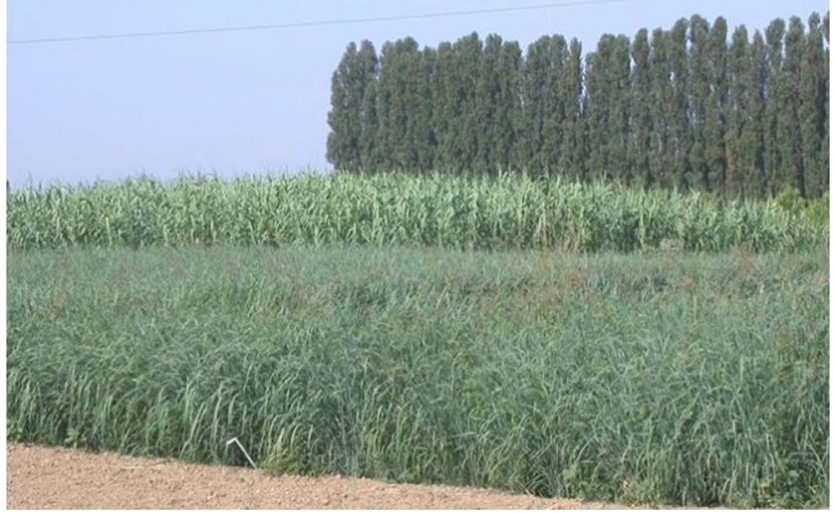

Fig. 1 Switchgrass and giant reed in Northern Italy, with poplar on the background

Understanding land-use-change effects on SOC will allow enhancing the life-cycle assessments of agro-energy systems, since, currently, the uncertainty in SOC dynamics still makes it difficult to give any exact figure. In many cases, SOC is not even included in the analyses (Davis et al. 2009), while, more commonly, generic coefficients of SOC changes are applied while implementing life-cycle assessments (Brandão and Milà i Canals 2013). Some studies instead (Adler et al. 2007; Gelfand et al. 2013; Hudiburg et al. 2016) employed biogeochemical models to account for biogenic impact on $\mathrm{CO}_{2}$ emissions, allowing a greater accuracy in assessing SOC dynamics. In fact, compared to generic coefficients, such models (e.g., DAYCENT) can account for small differences in C pools, soil dynamics, and land management, therefore owing the power to distinguish the effects on SOC even of crops with analogous uses and similar managements. However, in order to be properly calibrated, such models need measured, reliable data.

In general, land-use changes to perennial grasses have been investigated after arable crops or after native vegetation (Qin et al. 2016). Biomass supply districts in marginal areas might not include food crops (less suitable for low-productivity marginal areas) but only perennial grasses and short rotation coppices that succeed one another. In this context, long-term SOC variations caused by the land-use change from short rotation coppices to perennial grasses could constitute valuable information for the near future. Furthermore, understanding the real contribution of the current vegetation to SOC may constitute an important indication of the accumulation potential of a certain land use. In fact, a recent high deposition of organic matter may be canceled by a fast turnover of older organic matter, thus apparently resulting in a null contribution from the current land use. Garten and Wullschleger (2000), for example, converted pastures to switchgrass and, although they always observed an increase in switchgrass-derived SOC, they did not find a positive SOC gain in all sites; hence, older $\mathrm{C}$ losses counterbalanced the deposition of new C. Isotopic determinations (Balesdent et al. 1987; Garten and Wullschleger 2000) allow a deeper insight on SOC dynamics and to study the interactions between older SOC and newer SOC as, for the present case, an effect of the long-term succession of perennial crops.

To the best of our knowledge, although the effects on SOC of switchgrass, and to a less extent of giant reed, have been investigated (Monti et al. 2012 and references therein, Ceotto and Di Candilo 2011; Sarkhot et al. 2012; Cattaneo et al. 2014; Monti and Zegada-Lizarazu 2016), this is the first study that addressed the SOC variation under switchgrass and giant reed following poplar. Indeed, to present, no study has investigated the land-use change from woody biomass crops to herbaceous biomass crops (Fig. 1). Moreover, although both switchgrass and giant reed (Lewandowski et al. 2003) are among the most interesting herbaceous species for bioenergy and may thus compete for the same lands, their ability to increase SOC has never been quantified side-by-side. Sampling the soil to a depth of $0.6 \mathrm{~m}$ was believed effective in capturing the majority of the SOC variation as root $\mathrm{C}$ deposition rapidly decreases with soil depth (Garten and Wullschleger 2000; Collins et al. 2010); Garten and Wullschleger (2000) estimated that, in switchgrass, the surface $0.4 \mathrm{~m}$ of the soil contained 75 to $95 \%$ of the SOC inventory in the top $3 \mathrm{~m}$ of the soil. Several other studies on SOC dynamics of switchgrass and giant reed have considered the same soil layer or shallower (Kucharik 2007; Ceotto and Di Candilo 2011; Cattaneo et al. 2014; Fagnano et al. 2015; Monti and Zegada-Lizarazu 2016). The study covered a period of 10 years which is considered appropriate to provide reliable results on SOC variation (Qin et al. 2016). The experiment aimed to (1) measure the long-term SOC change occurring after the land-use change from a short rotation coppice to perennial herbaceous biomass crops, (2) compare side-by-side switchgrass and giant reed in their ability to increase SOC stocks, (3) study the rates of decomposition of poplar-derived SOC and of deposition of switchgrass-derived SOC after the land-use change, and (4) assess the impact of SOC changes on the life-cycle emissions by switchgrass and giant reed.

\section{Materials and methods}

\subsection{Experimental setup}

The trial was carried out on a flat, clay-loam sub-alkaline soil (Table 1) in Bologna, North Italy $\left(44^{\circ} 34^{\prime} \mathrm{N}, 11^{\circ} 47^{\prime} \mathrm{E} ; 5 \mathrm{~m}\right.$ a.s.l.) over a period of 10 years. The climate is characterized by cold humid winters and hot summers. During the trial (2005-2014), mean annual temperature was $13.4 \pm 8.3{ }^{\circ} \mathrm{C}$ $\left(17.8 \pm 6.3{ }^{\circ} \mathrm{C}\right.$, March to October), and rainfall was $613 \pm 150 \mathrm{~mm}(409 \pm 87 \mathrm{~mm}$, March to October). Poplar (Populus $\times$ euramericana, cultivar I-214) was the previous crop for 30 years. Poplar was harvested and uprooted in autumn 2003. The soil was then subject to a moldboard plowing 
Table 1 General soil characteristics at the experiment site $(0-0.5 \mathrm{~m})$

\begin{tabular}{llll}
\hline Parameter & Method & Unit & Value \\
\hline Gravel & Sieving $(>2 \mathrm{~mm})$ & $\%$ & $\mathrm{~ns}$ \\
Sand & Particle size an. $(0.05 \mathrm{~mm}<2 \mathrm{~mm})$ & $\%$ & 21 \\
Silt & Particle size an. $(0.002 \mathrm{~mm}<0.05 \mathrm{~mm})$ & $\%$ & 51 \\
Clay & Particle size an. $(<0.002 \mathrm{~mm})$ & $\%$ & 28 \\
$\mathrm{pH}$ & Soil-water suspension & & 7.5 \\
Total nitrogen & Dumas & $\mathrm{g} \mathrm{kg}^{-1}$ & 1.4 \\
Total limestone & Dietrich-Fruehling & $\%$ & 18.3 \\
Available phosphorus & Olsen & $\mathrm{mg} \mathrm{kg}^{-1}$ & 12 \\
Exchangeable potassium & Spectrophotometry & $\mathrm{mg} \mathrm{kg}^{-1}$ & 315 \\
\hline
\end{tabular}

ns not significant before winter and to harrowing in spring before establishing the two perennial crops: switchgrass (Panicum virgatum L.; var. Alamo) and giant reed (Arundo donax L.; local ecotype).

Switchgrass was sown on the 12th of May at seed density of 400 seeds $\mathrm{m}^{-2}$ (48-cm row spacing) by a mechanical seeder (Garavini 1225, Italy). Giant reed was transplanted on the 5th of July: furrows with an inter-row of $1 \mathrm{~m}$ were created, and then giant-reed seedlings were laid down within each furrow at the distance of $1 \mathrm{~m}$ from each other, resulting in a plant density of $1 \times 1 \mathrm{~m}$. Both crops were established in large plots ( $2250 \mathrm{~m}^{2}$ each, $15 \times 150 \mathrm{~m}$ ), according to randomized blocks with three replications. Plots were separated by $10-\mathrm{m}$ wide uncultivated rows. Both grasses were never fertilized with $\mathrm{N}$, whereas phosphate $(\mathrm{P})$ was distributed at a dose of $44 \mathrm{~kg}$ $\mathrm{ha}^{-1}$ only in the first year during field preparation. Potassium (K) was not supplied given the high soil content (Table 1). To ensure a successful establishment, 165 (switchgrass) and 210 (giant reed) $\mathrm{mm}$ of irrigation water were supplied during the first year. Both species were annually harvested in February: stems were cut at $\sim 5 \mathrm{~cm}$ from the ground, and then the biomass was baled.

\subsection{Soil organic carbon and isotope composition}

Soil organic carbon content was determined on three soil layers (0-0.2, 0.2-0.4, 0.4-0.6 m) the day before sowing switchgrass and again after the third (February 2007) and tenth harvest (February 2014). Given the large plot size $\left(2250 \mathrm{~m}^{2}\right)$, three soil samples per plot were collected (108 soil cores in total). Soil cores (70 $\mathrm{mm} \phi)$ were collected during harvest by a mechanical auger coupled with a tractor. Soil samples were air-dried and entirely ground to $0.5 \mathrm{~mm}$ prior to organic $\mathrm{C}$ determinations. Soil sub-samples (about $15 \mathrm{mg}$ ) were pre-treated with $\mathrm{HCl}$ to eliminate inorganic $\mathrm{C}$ and encapsulated thereafter. SOC was determined by an elemental analyzer (Flash $2000 \mathrm{CHNS} / \mathrm{O}$ Analyzer, Thermo Scientific, USA).

Given the different photosynthetic pathways of switchgrass (C4) and poplar (C3), carbon isotope composition was used (determined through CF-IRMS continuous-flow isotope-ratio mass spectrometer, Delta V Advantage, Thermo Scientific, USA) to estimate switchgrass contribution to SOC, as given by Balesdent et al. (1987):

$C_{s w}=C_{t}^{*}\left[\left(\delta^{13} C_{t}-\delta^{13} C_{0}\right) /\left(\delta^{13} C_{\mathrm{s}}-\delta^{13} C_{0}\right)\right]$

where $C_{s w}, C_{t}$, and $\delta^{13} C_{t}$ are switchgrass-derived C, total soil organic $\mathrm{C}$, and soil ${ }^{13} \mathrm{C}$ abundance relative to ${ }^{12} \mathrm{C}$ at time $t$, respectively. $\delta^{13} C_{0}$ and $\delta^{13} C_{s}$ are the ${ }^{13} \mathrm{C} /{ }^{12} \mathrm{C}$ abundance in the soil prior to switchgrass and of switchgrass plant tissues, respectively. Switchgrass roots (extracted from $70 \mathrm{~mm} \phi$ soil cores) and dead litter (collected on $0.25 \mathrm{~m}^{2}$ sampling areas) were collected in March 2015, separated from soil, washed, sieved, cleaned, oven-dried at $60^{\circ} \mathrm{C}$ for $72 \mathrm{~h}$, and finally ground $(0.5 \mathrm{~mm})$ prior to isotope determinations. The same procedure used for the soil samples was also used to determine the carbon isotope ratio of the plant material, although the amount of subsample encapsulated for the analysis differed $(\sim 0.5 \mathrm{mg})$. Root and litter showed very similar $\delta^{13} \mathrm{C}$ values $(-13.98 \% \circ \pm 0.44$ and $-14.00 \% \pm 0.29$, respectively).

\subsection{C credits from advanced bioethanol production}

The greenhouse-gas emissions deriving from the agricultural management of the two grasses were estimated through lifecycle assessment procedures (IPCC 2014) using SimaPro 8.0 (PRé Consultants, Amersfoort, NL), according to the IPCC 2013 GWP methodology (IPCC 2014). Life-cycle emissions were annualized for the 10 years of cultivation of the two crops, as the credits from SOC storage. Processes already present in the ecoinvent 3.0 database were adjusted to better reflect the real field management of the two grasses (Table 2). Cradle-to-farm gate impacts of both, switchgrass and giant reed, were then compared on a land- (hectare) basis. Fossil fuel offset credits from the production of advanced ethanol were estimated taking into account the aboveground biomass productions. Year by year yields of switchgrass and giant reed in this experiment were 
Table 2 List of field operations and agronomic inputs used to estimate life-cycle emissions from switchgrass and giant reed cultivated in Campotto (Northern Italy) in the years 2004-2014. Besides harvest that occurred yearly, all the remaining operations and inputs occurred only during establishment; hence, the emissions deriving from them were annualized (10 years)

\begin{tabular}{llll}
\hline Inputs & Units & Switchgrass & Giant reed \\
\hline Plowing & $\mathrm{n}$ & 1 & 1 \\
Harrowing (disk-grubber) & $\mathrm{n}$ & 1 & 1 \\
Rotary cultivator & $\mathrm{n}$ & 1 & 1 \\
Seeds & $\mathrm{kg} \mathrm{ha}^{-1}$ & 4.2 & - \\
Seedlings & $\mathrm{n} \mathrm{ha}^{-1}$ & - & 10000 (ten thousand) \\
P fertilizer & $\mathrm{kg} \mathrm{ha}^{-1}$ & 44 & 44 \\
Irrigation & $\mathrm{mm}_{\text {Hoeing }}$ & 165 & 210 \\
Harvesting & $\mathrm{n}$ & 1 & 1 \\
& type & baling & baling \\
\hline
\end{tabular}

reported elsewhere (Alexopoulou et al. 2015). For bioethanol conversion, we assumed 2821 of EtOH (21.1 $\mathrm{MJ} \mathrm{1}^{-1}$ ) produced from a ton of dry biomass (Lynd et al. 2008). Estimated carbon credits from fossil fuel offset were calculated assuming that $89.7 \mathrm{~g}$ of $\mathrm{CO}_{2}$ are saved for MJ of bioethanol energy (Gelfand et al. 2013) (Table 2).

\subsection{Sensitivity analysis of SOC stocks changes}

Through a sensitivity analysis, in which soil bulk density values were varied, we estimated the range of SOC stocks variation of switchgrass and giant reed. First, the soil-water content at saturation was estimated by employing the correlation found by Saxton et al. (1986) between soil texture and soil-water characteristics:

Saturation $=\left[0.332-\left(7.251^{-4}\right) \times(\%\right.$ sand $)+0.1276 \times \log _{10}(\%$ clay $\left.)\right](2)$

where \%sand and \%clay are the relative content of sand and clay of the soil, respectively. Then soil bulk density $(B D)$ was inferred through the following equation:

$B D=(1-$ Saturation $) \times 2.65$

We then assumed that soil bulk density could have been as low as $-20 \%\left(1.06 \mathrm{~g} \mathrm{~cm}^{-3}\right)$ or as high as $+20 \%\left(1.58 \mathrm{~g} \mathrm{~cm}^{-3}\right)$ of the calculated value $\left(1.32 \mathrm{~g} \mathrm{~cm}^{-3}\right)$ as well as that soil bulk density may have increased in time by up to $18 \%$ since establishment due to compaction (Onstad et al. 1984); we consider this latter assumption reasonable as part of the soil compaction already occurred before the initial sampling due to 5 months of weathering after plowing (December to May). Hence, by converting the gravimetric data to areal $\mathrm{C}$ stocks (Lee et al. 2009), the range within which SOC stocks changed was calculated.

\subsection{Statistical analysis}

All data were subject to one-way repeated measures analysis of variance (ANOVA); the year was considered a random factor. When ANOVA revealed significant differences among means $(P \leq 0.05)$, Fisher's LSD $(P \leq 0.05)$ test was used to separate means into groups.

\section{Results and discussion}

\subsection{Long-term carbon storage in the soil}

Both switchgrass and giant reed increased SOC in a period of 10 years (Fig. 2) after having replaced poplar. Giant reed, in particular, significantly increased SOC by $2.3(P \leq 0.01)$ and $1.5(P \leq 0.05) \mathrm{g} \mathrm{kg}^{-1}$ in the upper $(0-0.2 \mathrm{~m})$ and intermediate $(0.2-0.4 \mathrm{~m})$ soil layers, respectively, showing a double mean annual SOC accumulation rate than switchgrass (0.19 and $0.09 \mathrm{~g} \mathrm{~kg}^{-1}$ year ${ }^{-1}$, respectively). As poplar is broadly recognized for its ability to accumulate high amounts of soil carbon (Rytter 2012; Agostini et al. 2015), we were hypothesizing a decrease in SOC, especially in the first years of grass cultivation, so the measured further increase in SOC was unexpected.

The higher SOC increase of giant reed compared to switchgrass can be likely explained by the higher below- and aboveground biomass development of giant reed (Monti and Zatta 2009; Alexopoulou et al. 2015). Biomass residues (unrecovered biomass) of giant reed were also more than twice those of switchgrass ( $+105 \%$ of leaf-litter, data not shown); although leaves debris are generally more easily decomposable than root material (Kemp et al. 2003), this contributes in explaining the higher SOC under giant reed. Root size is another major factor affecting SOC accumulation (Agostini et al. 2015), but this was found to be very similar $(250-300 \mu \mathrm{m})$ between switchgrass and giant reed (Monti and Zatta 2009). Root tissue chemistry can also affect SOC dynamics. Liang et al. (2015) showed that giant reed roots have a slow potential decomposition (1.80 $\mathrm{g} \mathrm{kg}^{-1}$ day $\left.^{-1}\right)$ and, among six other perennial grasses, the highest root lignin content and highest lignin/nitrogen ratio.

Remarkably, about the half (59 and 54\% in switchgrass and giant reed, respectively) of SOC was accumulated during the first 3 years, and then SOC accumulation rates decreased. Higher SOC accumulation rates in the early period were also observed in other studies on the same species (Kucharik 2007; Qin et al. 2016). In our stands, biomass yields also showed a descending trend starting from the fourth year (Alexopoulou et al. 2015); however, such a decline was irregular and difficult to associate with the decrease of SOC accumulation rates. The absence of $\mathrm{N}$ fertilization in our experiment may also have contributed to a progressive decrease of SOC accumulation rates. Lee et al. (2007), for example, showed that, under 
Fig. 2 Soil organic carbon (SOC) variation under switchgrass (SG) and giant reed (GR) in the upper $(0-0.2 \mathrm{~m})$ and intermediate $(0.2-$ 0.4 ) soil layers after 3 and 10 years of cultivation. For both grasses, poplar was the previous crop for 30 years. Error bars $1 \mathrm{SE}$

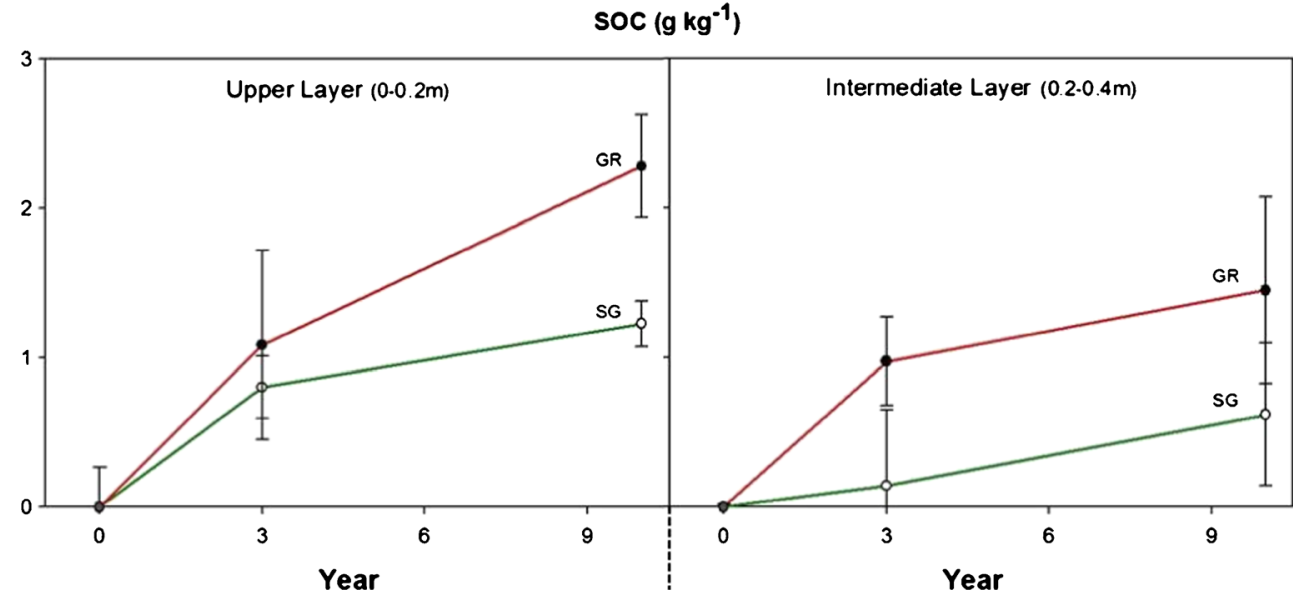

switchgrass, SOC gains can increase up to $+67 \%$ depending on $\mathrm{N}$-fertilization rates and fertilizer type (organic or synthetic). Again, in a 16-year study on $\mathrm{N}$ fertilization of giant reed, Monti and Zegada-Lizarazu (2016) found that SOC significantly increased with increasing N-fertilization rates. Garten and Wullschleger (2000) reported that the mineral-associated fraction of SOC is preponderant under switchgrass $(\sim 83 \%)$ and that it is more stable (mean residence time of about 2640 years) than the particulate organic matter fraction (mean residence time of about 3 years), which in fact tends to stabilize $C$ by associating it to the mineral fraction (13-15\% year $^{-1}$ transferred). Therefore, we may hypothesize that this stabilization becomes more difficult as the soil approach steady-state conditions, thus, when a $\mathrm{C}$ accumulation is occurring beneath switchgrass, the overall mean residence time of SOC decreases as less $\mathrm{C}$ is transferred to the mineral-associated fraction.

Regardless of the cause, the decreasing SOC accumulation rate after 3 years also suggests that $8-10$ years should be the minimal experimental frame for avoiding biased SOC estimations in perennial biomass crops (Qin et al. 2016). For example, if the present study had been limited to the first 3 years only (instead of 10 years), the annual equivalent SOC accumulation rate would be almost double $(0.16$ and $0.34 \mathrm{~g}$ (C) $\mathrm{kg}^{-1}$ year $^{-1}$, respectively, in switchgrass and giant reed).

\subsection{C4-derived SOC}

Switchgrass-derived SOC (upper 0.6-m soil depth) was insignificant ( $0.3 \%$ ) after 3 years, but was $9 \%$ after 10 years (Fig. 3). Other authors reported a contribution ranging from 12 to $24 \%$ after 9 and 5 years, respectively (Follett et al. 2012; Collins et al. 2010), but they considered very different soil layers of 1.5 and $0.15 \mathrm{~m}$, respectively. Although in their study, the soil was analyzed down to a double depth than in our experiment, Follett et al. (2012) found a similar contribution of switchgrass to SOC revealing that the overwhelming majority of $\mathrm{C}$ deposition occurred in the upper soil layers. At our site, switchgrass- derived SOC was higher in the upper soil layer (11\%), though significantly lower than that measured by other authors (Collins et al. 2010) at the same depth.

In the present study, poplar-derived SOC increased $\left(0.15 \mathrm{~g} \mathrm{~kg}^{-1}\right.$ year $\left.^{-1}\right)$ over the first 3 years after switchgrass establishment (Fig. 3). This could be easily explained by the decomposition of pre-existing poplar carbon sources, which may be characterized by a mean residence time of about 5 years, as previously reported by Cotrufo et al. (2005) who also operated on a loam soil. This was in fact verified by observing poplar-derived SOC decrease in the following 7 years $\left(-0.08 \mathrm{~g} \mathrm{~kg}^{-1}\right.$ year $\left.^{-1}\right)$. The high contribution of poplar-derived SOC to the soil inventory in the first 3 years seems, eventually, to clearly explain why accumulation rates decreased afterwards under both crops. For example, although Garten and Wullschleger (2000) found switchgrass-derived SOC to be always high (19-31\%) after 5 years in the top $0.4 \mathrm{~m}$ of soil, in two of their experimental sites where switchgrass had replaced a grassland, total SOC had decreased, showing how the very fast

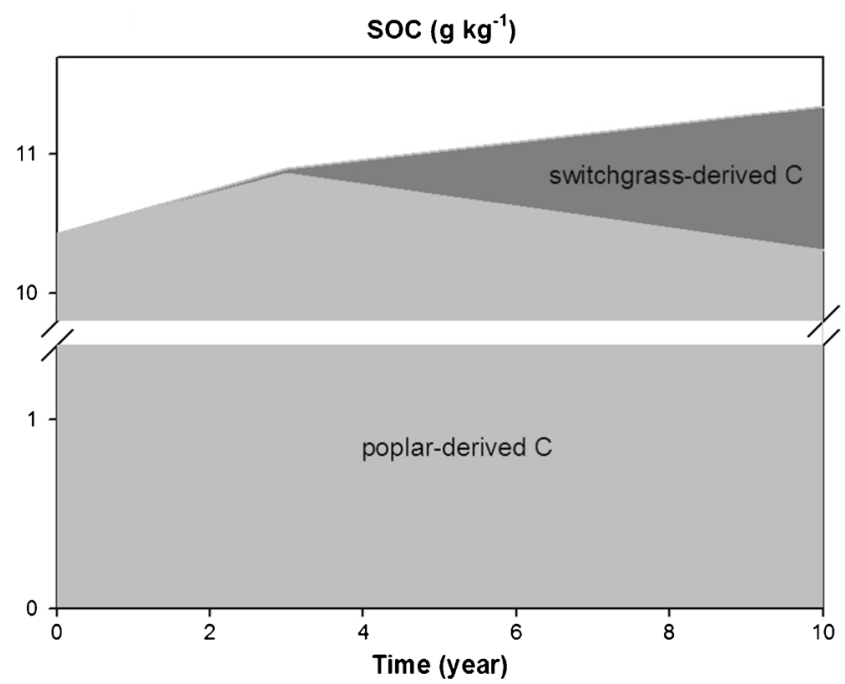

Fig. 3 Average switchgrass (C4)-derived SOC in the upper $0.4 \mathrm{~m}$ of soil after 10 years of cultivation following a poplar (C3) grove of 30 years 
turnover of the older organic matter nullified SOC deposition by switchgrass. Overall, in the 10 years, switchgrass-derived SOC increased at a rate that was higher than the rate of the net SOC increase ( 0.10 vs. $0.09 \mathrm{~g} \mathrm{~kg}^{-1}$ year $\left.^{-1}\right)$, as expected. The deposition of switchgrass-derived SOC exceeded the emissions of poplar-derived SOC, as the system had probably not reached yet steady-state conditions.

\subsection{Contribution to life-cycle $\mathrm{C}$ balance}

In the present study, global-warming emissions due to agronomic inputs resulted in 539 (switchgrass) and 637 (giant reed) $\mathrm{kg}\left(\mathrm{CO}_{2} \mathrm{e}\right) \mathrm{ha}^{-1}$ year $^{-1}(-0.15$ and $-0.17 \mathrm{Mg}$ of $\mathrm{C}$ $\mathrm{ha}^{-1}$ year $^{-1}$ ), while $\mathrm{C}$ savings from the conversion of lignocellulosic biomass to advanced bioethanol resulted in 2.0 and $3.1 \mathrm{Mg}(\mathrm{C}) \mathrm{ha}^{-1}$ year $^{-1}$, since mean biomass yields of switchgrass and giant reed corresponded to 13.6 and 21.2 $\mathrm{Mg} \mathrm{ha}^{-1}$ year $^{-1}$ (Alexopoulou et al. 2015), respectively. After the sensitivity analysis, we estimated that SOC stocks were increased by $0.37-1.58$ and $0.75-2.18 \mathrm{Mg} \mathrm{ha}^{-1}$ year $^{-1}$, respectively, beneath switchgrass and giant reed. It derives that SOC changes highly affected the overall $\mathrm{C}$ balance, accounting for the 11-35\% (switchgrass) and 20-42\% (giant reed) of total $\mathrm{C}$ savings. In two recent simulation studies on biofuel production from lignocellulosic feedstocks cultivated on US marginal land (i.e., grazing land, idle land), Gelfand et al. (2013) and Hudiburg et al. (2016) also underlined the relevance of SOC deposition (about 40 and 50\% contribution to life-cycle $\mathrm{C}$ savings, respectively), assuming high accumulation rates for switchgrass $\left(1.4 \mathrm{Mg} \mathrm{ha}^{-1}\right.$ year $\left.^{-1}\right)$ and miscanthus (2.4 $\mathrm{Mg} \mathrm{ha}^{-1}$ year $^{-1}$ ), whereas, previously, Adler et al. (2007) estimated a lower SOC accumulation under switchgrass, but that corresponded to almost the totality ( $\sim 80 \%$ ) of the estimated greenhouse-gas savings. Although SOC contribution to total savings estimated here was lower than in the aforementioned studies, in part because nitrousoxide emissions were not included in our study, our results confirm the substantial role of SOC in the sustainability of bioenergy cropping systems. Data as those presented in this study will turn out helpful in calibrating biogeochemical models (Adler et al. 2007; Gelfand et al. 2013; Hudiburg et al. 2016) during the assessment of greenhouse-gas impact of established biomass supply district, as presently in the literature the initial establishment of bioenergy crops has been experimented, but no successions of managed perennial crops yet.

Considerable uncertainties persist on the use of SOC in lifecycle assessments. Generic and standard SOC values are commonly used to estimate the carbon balance of agricultural systems (Brandão and Milà i Canals 2013), whereas, often, analyses are incomplete, not even including the land-use-change effect on SOC (Davis et al. 2009). Brandão and Milà i Canals (2013) analyzed the main drivers of the coefficients given by the
Intergovernmental Panel on Climate Change, commonly adopted to account for SOC variations. While initial SOC stocks are calculated using different factors (climate, soil type, and native vegetation), basically, SOC changes only depend on land-use management options. For example, according to the indications of the Intergovernmental Panel on Climate Change, the land-use change examined in our experiment, from poplar to switchgrass or from poplar to giant reed, should not cause any SOC change because perennial grasses and poplar are classified within the same vegetation category (Brandão and Milà i Canals 2013). On the opposite, we measured a substantial SOC accumulation, which was also substantially different between switchgrass and giant reed.

\section{Conclusions}

We estimated the effect on SOC of two perennial biomass grasses (switchgrass and giant reed) following a short rotation coppice (poplar). As poplar is broadly recognized for its ability in increasing SOC, we expected to detect a decrease or a steady SOC content in the two succeeding perennial grasses. In contrast, 10 years of switchgrass and giant reed caused a further increase of SOC, at an almost double rate in giant reed than switchgrass ( 0.19 and $0.09 \mathrm{~g} \mathrm{~kg}^{-1}$ year $\left.^{-1}\right)$. Poplar-derived SOC further increased in the initial years of switchgrass likely due to the decomposition of residual poplar biomass; however, switchgrass-derived SOC rapidly increased thereafter, up to $9 \%$ of total SOC after 10 years. Basing on a life-cycle assessment, SOC storage substantially affected final $\mathrm{C}$ savings by switchgrass and giant reed.

These are the first data on SOC inventories and SOC dynamics measured after the land-use change from a perennial biomass crop to other perennial biomass crops. This particular type of land-use change, which, to our knowledge, has not been considered yet in the literature, might become common in the near future within biomass supply districts. In the experiment, the crops were cultivated in large plots that allowed a fully mechanized system reproducing real operational conditions, while the experimental time-frame was long enough to simulate the perennial crops economic lifespan.

Finally, the study underlines the importance of punctual, accurate, and crop-specific determinations of SOC changes upon land-use change to avoid biased estimations of $\mathrm{C}$ savings, given by the application of coefficients to generic vegetation categories. Crop-specific data under determined crop sequences should be therefore incorporated within life-cycle inventories and biogeochemical models.

Acknowledgments The present study was supported by the European Projects: Optimization of Perennial Grasses for Biomass Production (OPTIMA-EU-FP7, 289642) and development of improved perennial 
non-food biomass and bioproduct crops for water-stressed environments (WATBIO-EU-FP7, 311929).

\section{References}

Adler PR, Del Grosso SJ, Parton WJ (2007) Life-cycle assessment of net greenhouse-gas flux for bioenergy cropping systems. Ecol Appl 17: 675-691. doi:10.1890/05-2018

Agostini F, Gregory AS, Richter GM (2015) Carbon sequestration by perennial energy crops: is the jury still out? Bioenerg Res 8:10571080. doi:10.1007/s12155-014-9571-0

Alexopoulou E, Zanetti F, Scordia D, Zegada-Lizarazu W, Christou M, Testa G, Cosentino SL, Monti A (2015) Long-term yields of switchgrass, giant reed and miscanthus in the Mediterranean basin. Bioenerg Res 8:1492-1499. doi:10.1007/s12155-015-9687-x

Balesdent J, Mariotti A, Guillet B (1987) Natural ${ }^{13} \mathrm{C}$ abundance as a tracer for studies of soil organic matter dynamics. Soil Biol Biochem 19:25-30. doi:10.1016/0038-0717(87)90120-9

Brandão M, Milà i Canals L (2013) Global characterization factors to assess land use impacts on biotic production. Int $\mathrm{J}$ Life Cycle Assess 18:1243-1252. doi:10.1007/s11367-012-0381-3

Cattaneo F, Barbanti L, Gioacchini P, Ciavatta C, Marzadori C (2014) ${ }^{13} \mathrm{C}$ abundance shows effective soil carbon sequestration in miscanthus and giant reed compared to arable crops under Mediterranean climate. Biol Fert Soils 50:1121-1128. doi:10.1007/s00374-014-0931-x

Ceotto E, Di Candilo M (2011) Medium-term effect of perennial energy crops on soil organic carbon storage. Ital J Agron 6:212-217. doi:10. 4081/ija.2011.e33

Collins HP, Smith JL, Fransen S, Alva AK, Kruger CE, Granatstein DM (2010) Carbon sequestration under irrigated switchgrass (Panicum virgatum L.) production. Soil Sci Soc Am J 74:2049-2058. doi:10. 2136/sssaj2010.0020

Cotrufo MF, De Angelis P, Polle A (2005) Leaf litter production and decomposition in a poplar short-rotation coppice exposed to free air $\mathrm{CO}_{2}$ enrichment (POPFACE). Glob Chang Biol 11:971-982. doi:10.1111/j.1365-2486.2005.00958.x

Davis SC, Anderson-Teixeira KJ, DeLucia EH (2009) Life-cycle analysis and the ecology of biofuels. Trends Plant Sci 14:140-146. doi:10. 1016/j.tplants.2008.12.006

Fagnano M, Impagliazzo A, Mori M, Fiorentino N (2015) Agronomic and environmental impacts of giant reed (Arundo donax L.): results from a long-term field experiment in hilly areas subject to soil erosion. Bioenerg Res 8:415-422. doi:10.1007/s12155-014-9532-7

Fargione J, Hill J, Tilman D, Polasky S, Hawthorne P (2008) Land clearing and the biofuel carbon debt. Science 319:1235-1238. doi:10. 1126/science. 1152747

Follett RF, Vogel KP, Varvel GE, Mitchell RB, Kimble J (2012) Soil carbon sequestration by switchgrass and no-till maize grown for bioenergy. Bioenerg Res 5:866-875. doi:10.1007/s12155-0129198-y

Garten CT Jr, Wullschleger SD (2000) Soil carbon dynamics beneath switchgrass as indicated by stable isotope analysis. J Environ Qual 29:645-653. doi:10.2134/jeq2000.00472425002900020036x

Gelfand I, Sahajpal R, Zhang X, Izaurralde RC, Gross KL, Robertson GP (2013) Sustainable bioenergy production from marginal lands in the US Midwest. Nature 493:514-517. doi:10.1038/nature11811

Hudiburg TW, Wang W, Khanna M, Long SP, Dwivedi P, Parton WJ, Hartman M, DeLucia EH (2016) Impacts of a 32-billion-gallon bioenergy landscape on land and fossil fuel use in the US. Nature Energy 1:1-7. doi:10.1038/nenergy.2015.5
IPCC (2014) Fifth Assessment Report. Available at: https://www.ipcc.ch/ report/ar5/

Kemp PR, Reynolds JF, Virginia RA, Whitford WG (2003) Decomposition of leaf and root litter of Chihuahuan desert shrubs: effects of three years of summer drought. J Arid Enriron 53:21-39. doi:10.1006/jare.2002.1025

Kucharik CJ (2007) Impact of prairie age and soil order on carbon and nitrogen sequestration. Soil Sci Soc Am J 71:430-441. doi:10.2136/ sssaj2006.0074

Lee DK, Owens VN, Doolittle JJ (2007) Switchgrass and soil carbon sequestration response to ammonium nitrate, manure and harvest frequency on Conservation Reserve Program land. Agron J 99: 462-468. doi:10.2134/agronj2006.0152

Lee J, Hopmans JW, Rolston DE, Baer SG, Six J (2009) Determining soil carbon stock changes: simple bulk density corrections fail. Agric Ecosyst Environ 134:251-256. doi:10.1016/j.agee.2009.07.006

Lemus R, Lal R (2007) Bioenergy crops and carbon sequestration. Crit Rev Plant Sci 24:1-21. doi:10.1080/07352680590910393

Lewandowski I, Scurlock JMO, Lindvall E, Christou M (2003) The development and current status of perennial rhizomatous grasses as energy crops in the US and Europe. Biomass Bioenergy 25:335361. doi:10.1016/S0961-9534(03)00030-8

Liang X, Erickson JE, Silveira ML, Sollenberger LE, Rowland DL (2015) Tissue chemistry and morphology affect root decomposition of perennial bioenergy grasses on sandy soil in a sub-tropical environment. GCB Bioenergy 8:1015-1024. doi:10.1111/gcbb.12315

Lynd LR, Laser MS, Bransby D, Dale BE, Davison B, Hamilton R, Himmel M, Keller M, McMillan J, Sheehan J, Wyman CE (2008) How biotech can transform biofuels. Nat Biotechnol 26:169-172. doi:10.1038/nbt0208-169

Monti A, Zatta A (2009) Root distribution and soil moisture retrieval in perennial and annual energy crops in Northern Italy. Agric Ecosyst Environ 132:252-259. doi:10.1016/j.agee.2009.04.007

Monti A, Zegada-Lizarazu W (2016) Sixteen-year biomass yield and soil carbon storage of giant reed (Arundo donax L.) grown under variable nitrogen fertilization rates. Bioenerg Res 9:248-256. doi:10. 1007/s12155-015-9685-z

Monti A, Barbanti L, Zatta A, Zegada-Lizarazu W (2012) The contribution of switchgrass in reducing GHG emissions. GCB Bioenergy 4: 420-434. doi:10.1111/j.1757-1707.2011.01142.x

Onstad CA, Wolfe ML, Larson CL, Slack DC (1984) Tilled soil subsidence during repeated wetting. T ASAE 27:733-736

Qin Z, Dunn JB, Kwon H, Mueller S, Wander MM (2016) Soil carbon sequestration and land use change associated with biofuel production: empirical evidence. GCB Bioenergy 8:66-80. doi:10.1111/ gcbb. 12237

Rytter R (2012) The potential of willow and poplar plantations as carbon sinks in Sweden. Biomass Bioenergy 36:86-95. doi:10.1016/j. biombioe.2011.10.012

Sarkhot DV, Grunwald S, Ge Y, Morgan CLS (2012) Total and available soil carbon fractions under the perennial grass Cynodon dactylon (L.) Pers and the bioenergy crop Arundo donax L. Biomass Bioenergy 41:122-130. doi:10.1016/j.biombioe.2012.02.015

Saxton KE, Rawls WJ, Romberger JS, Papendick RI (1986) Estimating generalized soil-water characteristics from texture. Soil Sci Soc Amer J 50:1031-1036. doi:10.2136/sssaj1986. 03615995005000040039x

Schmidt T, Fernando AL, Monti A, Rettenmaier N (2015) Life cycle assessment of bioenergy and bio-based products from perennial grasses cultivated on marginal land in the Mediterranean region. Bioenerg Res 8:1548-1561. doi:10.1007/s12155-015-9691-1 